\title{
Total and Bioaccessible Soil Arsenic and Lead Levels and Plant Uptake in Three Urban Community Gardens in Puerto Rico
}

\author{
John Misenheimer ${ }^{1}$, Clay Nelson ${ }^{2, *}$, Evelyn Huertas ${ }^{3}$, Myriam Medina-Vera ${ }^{2}$, Alex Prevatte ${ }^{4}$ \\ and Karen Bradham ${ }^{2}$ \\ 1 Oak Ridge Institute for Science and Education (ORISE) Research Participant, 109 TW Alexander Drive, \\ Research Triangle Park, Durham, NC 27711, USA; john.misenheimer0302@gmail.com \\ 2 U.S. Environmental Protection Agency, Office of Research and Development, 109 TW Alexander Drive, \\ Research Triangle Park, Durham, NC 27711, USA; medina-vera.myriam@epa.gov (M.M.-V.); \\ bradham.karen@epa.gov (K.B.) \\ 3 U.S. Environmental Protection Agency, Region 2-Caribbean Environmental Protection Division, Guaynabo, \\ PR 00968-8069, USA; Huertas.evelyn@Epa.gov \\ 4 Student Services Contractor at U.S. Environmental Protection Agency, Office of Research and Development, \\ 109 TW Alexander Drive, Research Triangle Park, Durham, NC 27711, USA; prevatte.alex@epa.gov \\ * Correspondence: nelson.clay@epa.gov; Tel.: +1-919-541-5617
}

Received: 31 October 2017; Accepted: 12 January 2018; Published: 26 January 2018

\begin{abstract}
Arsenic $(\mathrm{As})$ and lead $(\mathrm{Pb})$ are two contaminants of concern associated with urban gardening. In Puerto Rico, data currently is limited on As and $\mathrm{Pb}$ levels in urban garden soils, soil metal (loid) bioaccessibility, and uptake of $\mathrm{As}$ and $\mathrm{Pb}$ in soil by edible plants grown in the region. This study examined total and bioaccessible soil $\mathrm{As}$ and $\mathrm{Pb}$ concentrations and accumulation in 10 commonly grown garden plants collected from three urban community gardens in Puerto Rico. Bioavailability values were predicted using bioaccessibility data to compare site-specific bioavailability estimates to commonly used default exposure assumptions. Total and bioaccessible As levels in study soils ranged from 2 to $55 \mathrm{mg} / \mathrm{kg}$ and 1 to $18 \mathrm{mg} / \mathrm{kg}$, respectively. Total and bioaccessible Pb levels ranged from 19 to $172 \mathrm{mg} / \mathrm{kg}$ and 17 to $97 \mathrm{mg} / \mathrm{kg}$, respectively. Measured bioaccessibility values corresponded to $19 \%$ to $42 \%$ bioaccessible As and $61 \%$ to $100 \%$ bioaccessible $\mathrm{Pb}$ when expressed as a percent of total $\mathrm{As}$ and $\mathrm{Pb}$ respectively. Predicted relative percent bioavailability of soil $\mathrm{As}$ and $\mathrm{Pb}$ based on measured bioaccessibility values ranged from $18 \%$ to $36 \%$ and $51 \%$ to $85 \%$ for As and $\mathrm{Pb}$ respectively. Transfer factors (TFs) measuring uptake of As in plants from soil ranged from 0 to 0.073 in the edible flesh (fruit or vegetable) of plant tissues analyzed and 0.073 to 0.444 in edible leaves. $\mathrm{Pb}$ TFs ranged from 0.002 to 0.012 in flesh and 0.023 to 0.204 in leaves. Consistent with TF values, leaves accumulated higher concentrations of $\mathrm{As}$ and $\mathrm{Pb}$ than the flesh, with the highest tissue concentrations observed in the culantro leaf $(3.2 \mathrm{mg} / \mathrm{kg} \mathrm{dw}$ of As and $8.9 \mathrm{mg} / \mathrm{kg} \mathrm{dw} \mathrm{of} \mathrm{Pb})$. Leaves showed a general but not statistically-significant $(\alpha=0.05)$ trend of increased As and $\mathrm{Pb}$ concentration with increased soil levels, while no trend was observed for flesh tissues. These findings provide critical data that can improve accuracy and reduce uncertainty when conducting site-specific risk determination of potential $\mathrm{As}$ and $\mathrm{Pb}$ exposure while gardening or consuming garden produce in the understudied region of Puerto Rico.
\end{abstract}

Keywords: urban gardening; lead; arsenic; bioaccessibility; plant uptake; transfer factors; Puerto Rico

\section{Introduction}

Urban gardening, a growing trend in urban communities, is defined as the process of growing plants in an urban setting for consumption. However, this type of gardening poses the potential for 
contamination from historical site use and environmental history. The U.S. Environmental Protection Agency (USEPA) recommends steps to follow when developing urban garden sites, including sampling and testing the soil for contaminants [1]. Arsenic (As) and lead ( $\mathrm{Pb}$ ) are two potential contaminants of concern in urban gardens. As can originate from the underlying parent material or from anthropogenic additions from agriculture or industrial inputs [2]. Pb sources can include agricultural use of $\mathrm{Pb}$ arsenicals to control pests, $\mathrm{Pb}$ paint deposition, and air pollution deposition [3].

Direct oral ingestion of contaminated soil and consumption of plants that have accumulated As or $\mathrm{Pb}$ from underlying soil have been identified as exposure pathways of concern in urban garden soils that contain elevated levels of contaminants, including metals and metalloids (hereafter referred to collectively as metals) [1]. Human health risk assessments of toxic metals in soils based on total soil metal concentration can overpredict actual risk because only some percentage of metals in soil are in a form that will be absorbed in the gastrointestinal tract upon ingestion [4]. This is referred to as the bioavailable fraction. In vitro bioaccessibility (IVBA) assays that measure dissolution of metals from soil in a gastric like environment are commonly used as a reliable and cost effective estimate of soil metal bioavailability [5]. Therefore, metrics important in characterizing the potential for human exposure to toxic metals from urban gardens include total soil metal concentration, soil metal bioavailability/bioaccessibility, and edible plant tissue concentrations.

IVBA assays are an important tool for assessing potential human oral exposures from contaminated soil via the direct ingestion exposure pathway to determine the metal concentration available for absorption in the gastrointestinal tract $[4,5]$. These assays measure the solubility of $\mathrm{As}$ or $\mathrm{Pb}$ in a solution that simulates the human gastrointestinal tract and are used as a reliable estimate of relative bioavailability (RBA) tests that measure the fraction of ingested metal absorbed across the gastrointestinal barrier in vivo [4]. IVBA assays are an attractive alternative to directly measuring RBA in vivo due to their lower cost, higher throughput, and reduced reliance on animal testing. Understanding the relationship between $\mathrm{As}$ and $\mathrm{Pb}$ concentrations in soil and uptake by plants is also critical for characterizing potential exposure to these metals in urban gardens from consumption of edible plants.

Previous studies characterizing contaminant levels in urban garden produce have been conducted in regions throughout the world, including the United States [6,7], Great Britain [8-10], and China [11]. However, published research is limited on soil and plant As and $\mathrm{Pb}$ levels in the Caribbean region, including the U.S. territory of Puerto Rico. Because of regional and cultural differences in foods grown and consumed in urban gardens in different parts of the world, additional data are needed for understudied regions.

In this study, the total and bioaccessible fractions of $\mathrm{As}$ and $\mathrm{Pb}$ in garden soils and plant tissue concentrations sampled from three urban community gardens in Puerto Rico were measured to identify potential exposure concerns related to human health in local communities. RBA values were predicted based on measured IVBA values to compare site-specific bioavailability data to default bioavailability assumptions used in exposure and risk assessment. Differences in uptake by edible plants grown in the region were also investigated. Specifically, garden plant tissues analyzed were categorized as either leaf (such as lettuces and herbs) or flesh (fruits or vegetables), and differences in uptake between categories were explored based on calculated transfer factors (TFs), defined as the ratio of As or Pb concentration in the plant relative to the soil concentration. Ten garden plants (representing nine unique plant species) typical of those grown in urban gardens in Puerto Rico were investigated. These results add to the existing knowledge base for characterizing potential exposure to As and $\mathrm{Pb}$ from urban gardens, and provide important site-specific metal exposure information to local community members.

\section{Materials and Methods}

\subsection{Site Descriptions}

The soil and plant samples for this study were collected from three urban community garden sites in the Martin Peña District of San Juan, Puerto Rico, shown in Figure 1. The three garden sites are located in the region demarcated by the black border, but the exact locations are not disclosed to 
preserve the anonymity of these communities. The area is urbanized, with a river outlet splitting the district. Two of the sites originally were empty urban lots that were converted into gardens to improve the community's access to healthy food. The third garden site was created in 2012 as part of a school cooperative program. The Martin Peña District has a population of 26,000, an unemployment rate of $22 \%$, and approximately $53 \%$ of its inhabitants live in poverty.

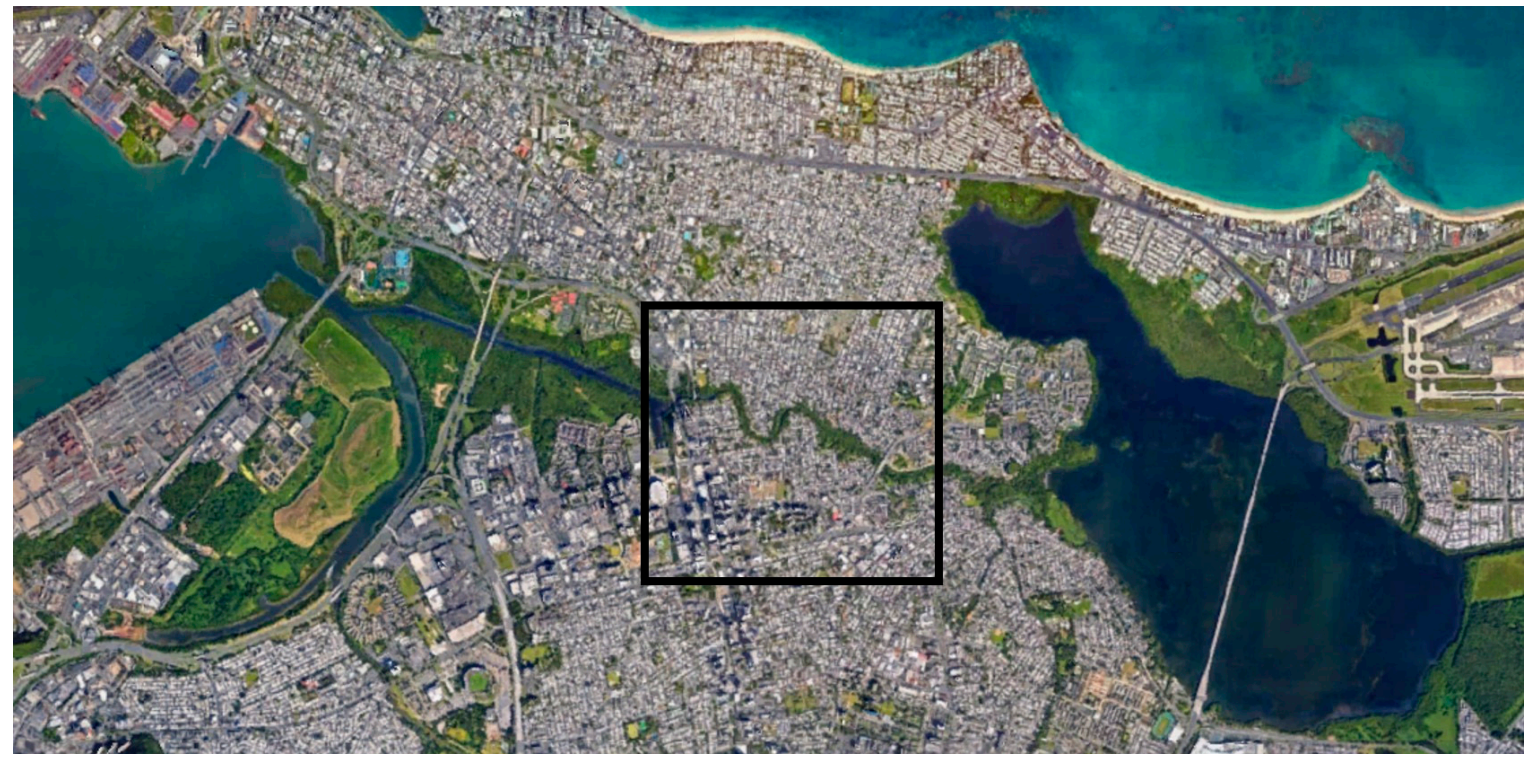

Figure 1. Satellite image [12] of area surrounding Martin Peña District of Puerto Rico, with the three urban community gardens located in the region in the black border.

\subsection{Plant and Soil Sample Collection}

Soil and plant tissue samples were collected from each of the three gardens and analyzed at a USEPA laboratory in Research Triangle Park, NC. Plants at each site were grown in raised beds with defined perimeters (such as concrete blocks or wooden boards), car tires filled with soil, or soil spread into a four-inch mound above grade (Figure 2).

Soil samples were collected from the top one-to-two inches of soil around each plant in accordance with USEPA guidance on sample collection for soil metal bioaccessibility determination [13]. A minimum of 100 grams (g) of soil was collected per sample. Five discrete soil samples were collected from each garden. A composite soil sample was also collected from each garden, which, in addition to the areas around individual garden plants analyzed in this study, included soil samples collected (randomly) from other areas of the gardens, for a total of 18 soil samples.

Samples of the edible portions of plants were also collected from each garden. Collected plants generally had shallow root systems (less than two inches deep). Therefore, soil below two inches in depth was not collected for this study. Plant samples were placed into labeled plastic bags and shipped to the USEPA laboratory for analysis. The USEPA laboratory analyzed only plant samples with sufficient mass (greater than $0.45 \mathrm{~g}$ on a dry weight (dw) basis), resulting in 10 garden plants samples being analyzed for this study. Samples consisted of the leaves of basil (from two unique basil plants), culantro, lettuce, and pumpkin plants and the flesh portions of avocado, tomato, sweet pepper, eggplant, and yucca fruits. Due to the season in which plant samples were collected, only the leaf of the pumpkin plant was available for sampling; the fruit had not yet developed. Pumpkin leaves are not commonly consumed in the United States or Puerto Rico, but inhabitants of some countries, including Malawi, Kenya, and some South Pacific countries, rely on the leaves as a source of nutrition [14-16]. The pumpkin leaf was therefore included in this study. 

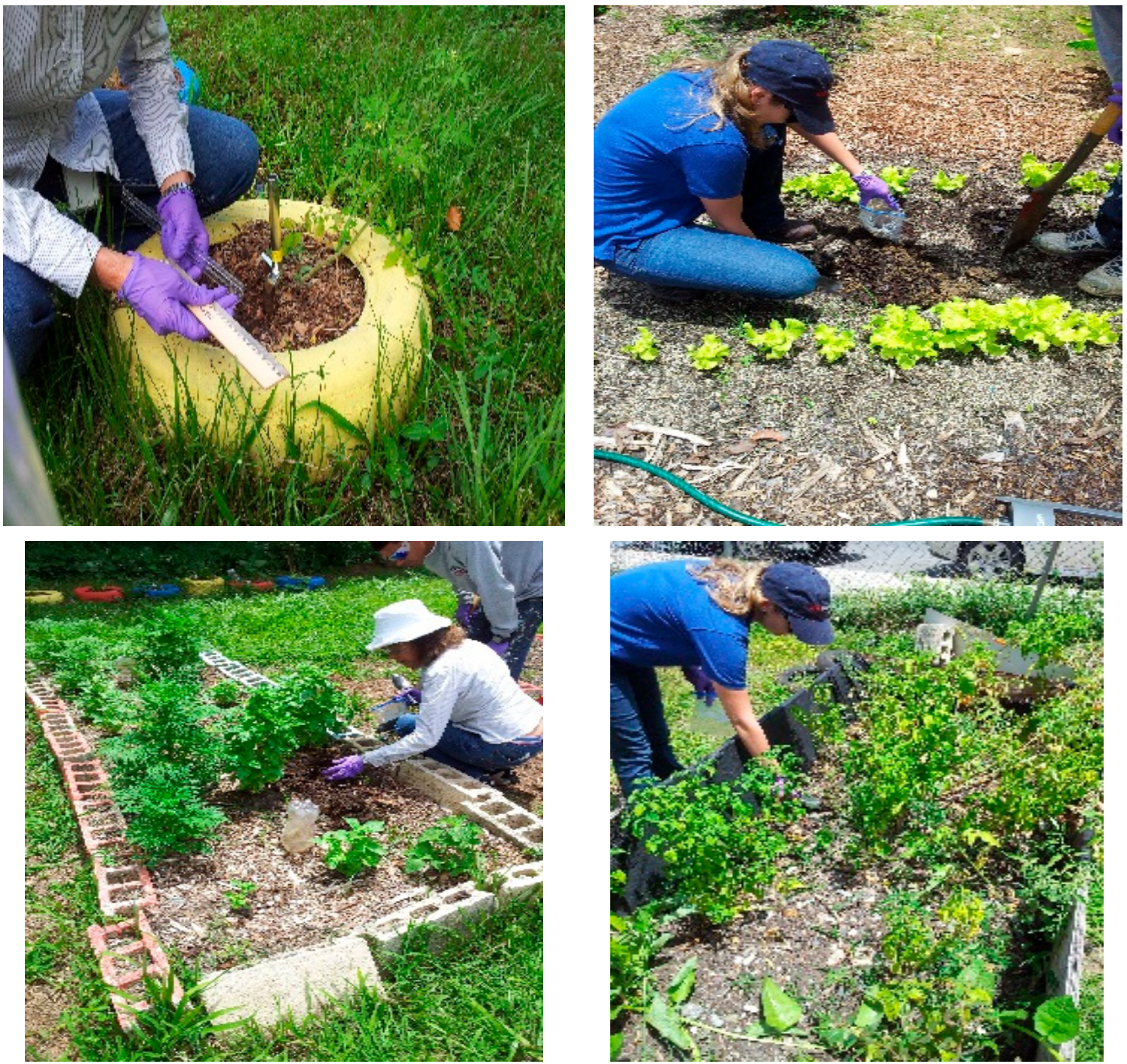

Figure 2. Examples of raised beds from the urban community gardens evaluated in this study.

\subsection{Soil Sample Processing and Physicochemical Characterization}

At the USEPA laboratory, the 18 soil samples were placed in an oven and dried for about five days at less than $40{ }^{\circ} \mathrm{C}$. A vibrating, 2-mm stainless-steel sieve removed large chunks of aggregate from the soil samples. Material remaining on the screen was disaggregated using a gloved hand and rescreened. The soil was sieved to less than $250 \mu \mathrm{m}$, the particle size fraction used for bioaccessibility testing [5]. Sieved soil was passed through a riffler five times, and aliquots were collected in clean 250-mL high-density polyethylene (HDPE) bottles for analysis. Total soil element concentrations were determined in duplicate samples of each soil by digesting soils in accordance with USEPA Method 3051 using a MARS-5 microwave system (CEM Corporation, Matthews, NC, USA). Soil samples were analyzed in accordance with USEPA Method 6010 using an iCAP 6000 series inductively coupled plasma (ICP)-optical emission spectrometry (OES) instrument (ThermoScientific, Waltham, MA, USA). For $\mathrm{pH}$ analysis, $2 \mathrm{~g}$ of each soil was placed into $10 \mathrm{~mL}$ of water and shaken for $1 \mathrm{~h} \mathrm{[17].}$

The soil sample As and $\mathrm{Pb}$ concentrations were compared to human health soil screening levels (SSLs) $[18,19]$. Pb soil concentrations were also compared to risk levels identified by a USEPA Technical Review Workgroup, which provided recommended guidelines to reduce lead exposure from gardening related activities based on soil $\mathrm{Pb}$ levels [20]. 


\subsection{Bioaccessibility Assays}

Bioaccessibility of $\mathrm{As}$ and $\mathrm{Pb}$ in soil samples was determined in accordance with USEPA Method 9200.2-86. Synthetic stomach fluid (SSF) was prepared using deionized water amended with 0.4 molar (M) glycine (certified American Chemical Society grade) acidified to a $\mathrm{pH}$ of 1.5 using hydrochloric acid $(\mathrm{HCl})(32 \%$ to $35 \%$ analytical grade) to mimic the high acidity environment in the stomach. Bioaccessibility assays were performed in duplicate for each soil and included the addition of $1 \mathrm{~g}$ of test soil to $100 \mathrm{~mL}$ SSF in a 125-mL HDPE bottle rotated end over end in a water bath at $37^{\circ} \mathrm{C} \mathrm{for} 1 \mathrm{~h}$. Extracted solutions were refrigerated at $4{ }^{\circ} \mathrm{C}$ for preservation and subsequent analysis using ICP-mass spectrometry (MS) (USEPA Method 6020).

As and $\mathrm{Pb}$ bioaccessibility was calculated and expressed on a percentage basis using Equation (1).

$$
\text { As } / \mathrm{Pb} \text { bioaccessibility }(\%)=\left(\frac{\text { in vitro } \mathrm{As} \text { or } \mathrm{Pb}\left(\frac{\mathrm{mg}}{\mathrm{kg}}\right)}{\text { total } \mathrm{As} \mathrm{or} \mathrm{Pb}\left(\frac{\mathrm{mg}}{\mathrm{kg}}\right)}\right) \times 100
$$

where "in vitro $\mathrm{As} / \mathrm{Pb}^{\prime}$ was the As or $\mathrm{Pb}$ extracted during the in vitro assay and "total $\mathrm{As} / \mathrm{Pb}$ " was the total amount of $\mathrm{As}$ or $\mathrm{Pb}$ in the soil used for bioaccessibility determination.

To compare site-specific metal bioavailability data from garden soils to default bioavailability assumptions that may be used when developing SSLs or conducting risk assessments at metal contaminated sites, in vitro bioaccessibility (IVBA) values were converted to relative bioavailability (RBA) predictions using validated linear models for As and $\mathrm{Pb}$. Specifically, Pb RBA was calculated based on USEPA Method 1340 [21] using Equation (2), and As RBA was calculated based on the linear model published by Diamond et al. [22] using Equation (3).

$$
\begin{gathered}
\operatorname{Pb} \operatorname{RBA}(\text { fraction })=0.878 \times \operatorname{Pb} \operatorname{IVBA}(\text { fraction })-0.028 \\
\text { As RBA }(\%)=0.79 \times \operatorname{As} \operatorname{IVBA}(\%)+3
\end{gathered}
$$

\subsection{Plant Sample Processing and Physicochemical Characterization}

At the USEPA laboratory, the plant samples were thoroughly rinsed with deionized water to remove residual soil, freeze-dried for 24 to $48 \mathrm{~h}$, hand ground to powder, and acid digested using a MARS-5 microwave system (CEM Corporation) in accordance with USEPA Method 3052. Because only the edible portion of the plants were of interest, the avocado was peeled before freeze drying. Plant samples with sufficient mass were analyzed in duplicate, with metal concentrations reported as the average of the concentrations of the two duplicates. Plant samples without enough mass to allow duplicate analysis yielded results for a single analysis only. Plant digests were diluted and analyzed by USEPA Method 6020 using a Thermo Scientific X-Series II ICP-MS. Quality control (QC) samples included analysis of an acid blank, blank spike, and National Institute of Standards and Technology Standard Reference Material (NIST SRM) (NIST 2710A) with each microwave digestion batch.

\subsection{Relationship of Soil As and Pb to Plant Uptake}

Ten soil samples were paired with their associated (co-located) garden plant sample (nine plant types, including two basil plants collected from two gardens). The other eight soil samples either did not have a garden plant associated with them or the plant sample did not contain sufficient mass for analysis. Plant tissues were categorized as either leaf (basil, culantro, lettuce, and pumpkin leaf) or flesh (avocado, tomato, sweet pepper, eggplant, and yucca). Relationships between soil and plant tissue $\mathrm{As}$ and $\mathrm{Pb}$ concentrations were investigated, and transfer factors (TFs), also commonly referred to as uptake or concentration factor, were calculated to quantify the accumulation of $\mathrm{As}$ and $\mathrm{Pb}$ in plant tissues using Equation (4) [23]. 


$$
\mathrm{TF}=\frac{\text { Concentration (plant) }}{\text { Concentration (soil) }}
$$

\section{Results}

\subsection{Soil As and Pb Levels}

Table 1 summarizes the soil total, measured bioaccessible, and predicted bioavailable As and $\mathrm{Pb}$ results for Gardens 1, 2, and 3. In the 18 soil samples analyzed, As total soil concentrations ranged from 2.0 to 55.4 milligrams per kilogram $(\mathrm{mg} / \mathrm{kg})($ mean $=9.0 \mathrm{mg} / \mathrm{kg})$, and $\mathrm{Pb}$ concentrations ranged from 19.1 to $172.0 \mathrm{mg} / \mathrm{kg}$ (mean $=44.6 \mathrm{mg} / \mathrm{kg}$ ). For reference, background As and $\mathrm{Pb}$ concentrations in soils sampled across the continental United States range from 0.1 to 97 and 2 to $300 \mathrm{mg} / \mathrm{kg}$, respectively [2]. Table 1 also presents the results for aluminum (Al), iron ( $\mathrm{Fe})$, and soil $\mathrm{pH}$ because these soil properties have been identified as influencing soil metal bioaccessibility [5,24,25].

Table 1. Total bioaccessible and bioavailable $\mathrm{As}$ and $\mathrm{Pb}$ in study soils and additional soil properties of interest.

\begin{tabular}{|c|c|c|c|c|c|c|c|c|c|c|}
\hline \multirow[b]{2}{*}{ Garden } & \multirow[b]{2}{*}{ Soil ID } & \multicolumn{3}{|c|}{ Arsenic } & \multicolumn{3}{|c|}{ Lead } & \multirow[b]{2}{*}{ Al (\%) } & \multirow[b]{2}{*}{$\mathrm{Fe}(\%)$} & \multirow[b]{2}{*}{$\mathrm{pH}$} \\
\hline & & $\begin{array}{c}\text { Total } \\
\text { (mg/kg) }\end{array}$ & IVBA (\%) ${ }^{1}$ & $\operatorname{RBA}(\%)^{2}$ & $\begin{array}{c}\text { Total } \\
(\mathrm{mg} / \mathrm{kg})\end{array}$ & IVBA (\%) ${ }^{1}$ & $\operatorname{RBA}(\%)^{3}$ & & & \\
\hline \multirow{6}{*}{1} & Soil 1 & 55.4 & 32 & 28 & 130.9 & 74 & 62 & 1.26 & 2.44 & 7.4 \\
\hline & Soil 2 & 14.8 & 29 & 26 & 87.0 & 77 & 65 & 1.10 & 2.17 & 7.8 \\
\hline & Soil 3 & 11.3 & 19 & 18 & 56.6 & 65 & 54 & 1.27 & 2.60 & 7.9 \\
\hline & Soil 4 & 9.8 & 21 & 20 & 82.2 & 63 & 53 & 1.23 & 3.24 & 8.0 \\
\hline & Soil 5 & 12.0 & 20 & 19 & 54.7 & 61 & 51 & 1.21 & 2.70 & 8.0 \\
\hline & Composite & 14.1 & 26 & 24 & 172.0 & 78 & 66 & 1.52 & 2.82 & 8.2 \\
\hline \multirow{6}{*}{2} & Soil 1 & $8.8^{4}$ & 24 & 22 & 34.5 & 65 & 54 & 2.19 & 3.24 & 7.9 \\
\hline & Soil 2 & $6.6^{4}$ & 24 & 22 & 30.7 & 68 & 57 & 1.42 & 2.42 & 7.8 \\
\hline & Soil 3 & $7.2^{4}$ & 24 & 22 & 43.6 & 73 & 61 & 1.35 & 2.32 & 7.8 \\
\hline & Soil 4 & $9.1^{4}$ & 25 & 23 & 35.9 & 78 & 66 & 1.40 & 2.50 & 7.9 \\
\hline & Soil 5 & $5.7^{4}$ & 20 & 19 & 21.6 & 61 & 51 & 1.25 & 1.90 & 7.6 \\
\hline & Composite & $8.8^{4}$ & 29 & 26 & 34.7 & 76 & 64 & 1.49 & 2.53 & 7.8 \\
\hline \multirow{6}{*}{3} & Soil 1 & $5.3^{4}$ & 24 & 22 & 41.7 & 72 & 60 & 0.86 & 2.06 & 8.0 \\
\hline & Soil 2 & $2.0^{4}$ & 32 & 28 & 19.1 & 87 & 74 & 1.10 & 1.82 & 7.9 \\
\hline & Soil 3 & $6.7^{4}$ & 42 & 36 & 22.9 & 100 & 85 & 1.56 & 2.36 & 8.0 \\
\hline & Soil 4 & $8.5^{4}$ & 31 & 27 & 40.0 & 75 & 63 & 0.96 & 2.15 & 8.0 \\
\hline & Soil 5 & $9.6^{4}$ & 22 & 20 & 30.1 & 93 & 79 & 1.27 & 2.38 & 7.9 \\
\hline & Composite & $8.1^{4}$ & 19 & 18 & 35.6 & 68 & 57 & 1.47 & 2.97 & 7.9 \\
\hline
\end{tabular}

\footnotetext{
${ }^{1}$ Measured directly using EPA Method 9200.2-86; ${ }^{2}$ Predicted based on the linear model developed by Diamond et al. [22];

${ }^{3}$ Predicted based on the linear model provided in EPA Method 1340 [21]; ${ }^{4}$ Values were below the reporting limit for As of $9.7 \mathrm{mg} / \mathrm{kg}$ and therefore considered estimated.
}

\subsection{Soil As and Pb Bioaccessibility and Bioavailability}

Across the 18 soil samples, As IVBA ranged from 19\% to 42\%. Estimated RBA values, predicted based on measured IVBA values, ranged from $18 \%$ to $36 \%$. Pb IVBA and RBA values ranged from $61 \%$ to $100 \%$ and $51 \%$ to $85 \%$ respectively (Table 1 ). Results for all associated quality control samples, including blanks, blank spikes, and NIST SRM 2710A standard reference material used to measure IVBA were within acceptable limits as defined by USEPA Method 9200.2-86.

\subsection{Plant Uptake of $\mathrm{As}$ and $\mathrm{Pb}$}

Table 2 summarizes As and $\mathrm{Pb}$ concentrations in plant tissues collected from the three gardens, along with the paired soil concentrations and TFs. Detectable As and $\mathrm{Pb}$ levels were observed in every plant sample analyzed except for the tomato, which had As levels below the method reporting limit of $0.04 \mathrm{mg} / \mathrm{kg}$ $\mathrm{dw}$. Plant tissue As concentrations ranged from less than 0.04 to $3.2 \mathrm{mg} / \mathrm{kg} \mathrm{dw}$. Pb concentrations ranged from 0.1 to $8.9 \mathrm{mg} / \mathrm{kg} \mathrm{dw}$. The highest concentrations for both As $(3.2 \mathrm{mg} / \mathrm{kg} \mathrm{dw})$ and $\mathrm{Pb}(8.9 \mathrm{mg} / \mathrm{kg} \mathrm{dw})$ 
were observed in the culantro leaf. All associated QC samples analyzed were within acceptable limits (i.e., $\pm 15 \%$ recovery of expected value or below method reporting limit for blanks).

Leafy plant tissues accumulated higher concentrations of $\mathrm{As}$ and $\mathrm{Pb}$ than the flesh of fruits and vegetables analyzed (Figure 3), with As TFs ranging from 0.073 to 0.444 and 0.000 to 0.073 for leaf and flesh plant tissues respectively. Pb TFs ranged from 0.058 to 0.204 and 0.002 to 0.012 for leaf and flesh plant tissues respectively.

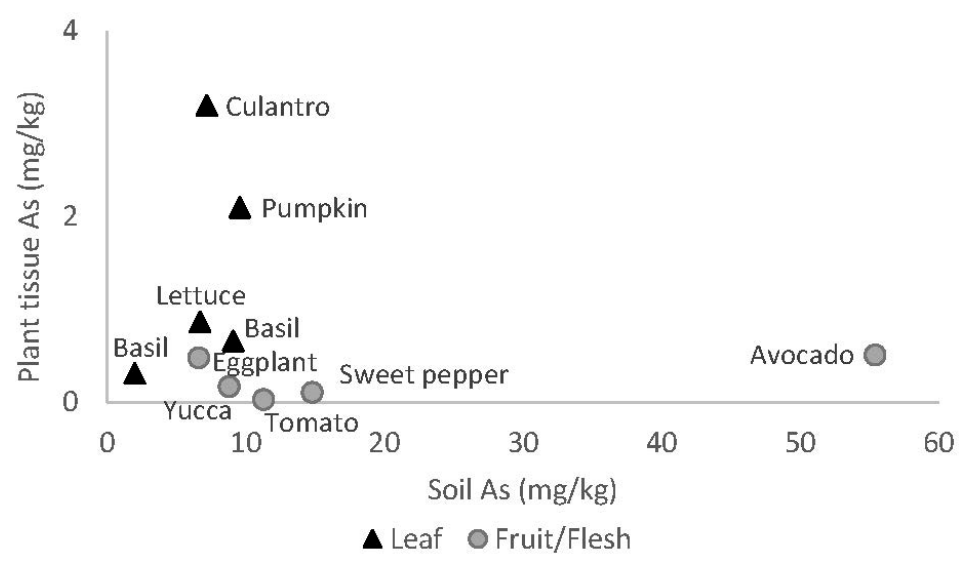

(a) Arsenic

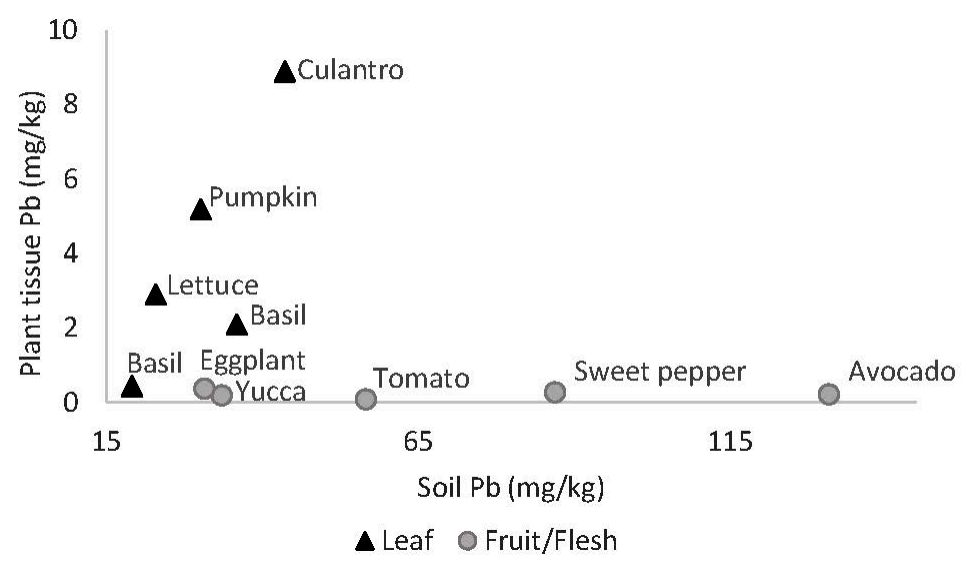

(b) Lead

Figure 3. Relationship between soil $\mathrm{As}$ and $\mathrm{Pb}$ concentration and uptake in plant tissues categorized as leaf or flesh.

Table 2. Paired plant and soil As and $\mathrm{Pb}$ concentrations with associated TFs. Plant concentrations reported on a dry weight basis.

\begin{tabular}{|c|c|c|c|c|c|c|c|c|}
\hline Garden & Plant & Tissue & Plant As (mg/kg) ${ }^{1}$ & $\begin{array}{l}\text { Soil As } \\
\text { (mg/kg) }\end{array}$ & As TF & $\begin{array}{l}\text { Plant Pb } \\
(\mathrm{mg} / \mathrm{kg})^{1}\end{array}$ & $\begin{array}{l}\text { Soil Pb } \\
\text { (mg/kg) }\end{array}$ & $\mathrm{Pb}$ TF \\
\hline \multirow{3}{*}{1} & Avocado & Flesh & $0.51 \pm 0.03$ & 55.4 & 0.009 & $0.22 \pm 0.02$ & 130.9 & 0.002 \\
\hline & Tomato & Flesh & $<0.04$ & 11.3 & 0.000 & $0.09 \pm 0.01$ & 56.6 & 0.002 \\
\hline & Sweet Pepper ${ }^{2}$ & Flesh & 0.11 & 14.8 & 0.007 & 0.28 & 87.0 & 0.003 \\
\hline \multirow{4}{*}{2} & Eggplant & Flesh & $0.48 \pm 0.22$ & 6.6 & 0.073 & $0.38 \pm 0.12$ & 30.7 & 0.012 \\
\hline & Yucca & Flesh & $0.17 \pm 0.01$ & 8.8 & 0.019 & $0.20 \pm 0.01$ & 33.5 & 0.006 \\
\hline & Basil & Leaf & $0.66 \pm 0.01$ & 9.1 & 0.073 & $2.1 \pm 0.1$ & 35.9 & 0.058 \\
\hline & Culantro $^{2}$ & Leaf & 3.2 & 7.2 & 0.444 & 8.9 & 43.6 & 0.204 \\
\hline \multirow{3}{*}{3} & Lettuce & Leaf & $0.87 \pm 0.01$ & 6.7 & 0.130 & $2.9 \pm 0.1$ & 22.9 & 0.127 \\
\hline & Pumpkin & Leaf & $2.1 \pm 0.1$ & 9.6 & 0.219 & $5.2 \pm 0.2$ & 30.1 & 0.173 \\
\hline & Basil $^{2}$ & Leaf & 0.31 & 2.0 & 0.155 & 0.44 & 19.1 & 0.023 \\
\hline
\end{tabular}

${ }^{1}$ Values reported as the average \pm standard deviation of two replicate samples unless otherwise noted; ${ }^{2}$ Only a single plant replicate was analyzed due to insufficient tissue mass for duplicate. 


\section{Discussion}

Human health SSLs for As in the United States based on the direct soil ingestion exposure pathway vary by state or region and generally range from 0.04 to $40 \mathrm{mg} / \mathrm{kg}$, which corresponds to a 1 in $1 \mathrm{million}$ to 1 in 10,000 incremental cancer risk [18]. SSLs are not remediation levels but rather guidelines to help determine if sites or portions of sites require further investigation. One soil sample from Garden 1 contained As at $55.4 \mathrm{mg} / \mathrm{kg}$, exceeding the highest aforementioned SSL of $40 \mathrm{mg} / \mathrm{kg}$. Other soils had As concentrations above some state-specific SSLs. However, As concentrations in these soils were closer to typical background levels of As in soil.

The USEPA has established $400 \mathrm{mg} / \mathrm{kg}$ as the human health SSL for Pb based on the direct soil ingestion exposure pathway, assuming a default RBA of $60 \%$ [19,26]. Residential areas with soil Pb concentrations below $400 \mathrm{mg} / \mathrm{kg}$ may require no additional action. However, some actions may be needed in gardens containing soil $\mathrm{Pb}$ concentrations below $400 \mathrm{mg} / \mathrm{kg}$ to reduce the potential for increased $\mathrm{Pb}$ exposure [20]. According to recommended guidelines regarding gardening, soil $\mathrm{Pb}$ levels under $100 \mathrm{mg} / \mathrm{kg}$ are considered low risk, with no additional action needed [20]. Most of the garden soil samples evaluated for $\mathrm{Pb}$ in this study were below this level. However, two soil samples from Garden 1 contained $\mathrm{Pb}$ at concentrations exceeding $100 \mathrm{mg} / \mathrm{kg}$ (131 mg and $172 \mathrm{mg} / \mathrm{kg}$ ).

All garden soils evaluated in this study had As RBA values (predicted based of measured IVBA values) at or below $36 \%$. Observed site-specific RBA values suggest exposure risk from oral ingestion of As from these garden soils would be less than that determined under scenarios where bioavailability data is not considered or a default RBA value of 60\% [27] is used. Pb RBA values in study soils ranged from $51 \%$ to $85 \%$, with the two soil samples that contained $\mathrm{Pb}$ above $100 \mathrm{mg} / \mathrm{kg}$ having predicted RBA values of $62 \%$ and $66 \%$, slightly above the default assumption of $60 \%$ used in development of screening levels of $\mathrm{Pb}$ contaminated soils. Because even small changes in bioavailability values used in risk determination can have significant impacts on calculated risk [4], the use of site-specific data rather than default assumptions can improve the accuracy of human health risk assessments of metal contaminated soils. While the in vitro bioaccessibility assay used in this study, which uses a stomach phase only, has been demonstrated as a reliable predictor of As [28,29] and Pb RBA [21], it should be noted that alternative in vitro bioaccessibility assays that use a two-phase system (gastric and intestinal phase) may result in differences in measured bioaccessibility or predicted RBA.

For garden soils that exceed $\mathrm{As}$ or $\mathrm{Pb}$ levels determined to be low risk for exposure, the USEPA recommends (1) decreasing the planting of root vegetables; (2) relocating plants to lower risk areas; (3) increasing soil amendments and barriers to reduce soil deposition onto leafy vegetables; (4) wearing gloves to reduce contact with and potential ingestion of soil; and (5) planting vegetables that are not in direct contact with the soil (such as fruit trees) [20].

While SSLs are typically based on the direct soil ingestion exposure pathway, consideration of the soil-plant-human exposure pathway may also be important to accurately characterize exposure to toxic metals in urban gardens, especially for As [30]. Consistent with previous research [31,32], plant TF data indicated that the garden plants in this study tended to concentrate As from soils in tissues more heavily than $\mathrm{Pb}$ across the range of observed soil $\mathrm{As}$ and $\mathrm{Pb}$ concentrations, with $\mathrm{As} \mathrm{TFs}$ averaging 0.105 compared to an average $\mathrm{Pb}$ TF of 0.056 . The higher concentrations of $\mathrm{Pb}$ than $\mathrm{As}$ in plant tissues observed in this study, therefore, were likely a result of the higher total $\mathrm{Pb}$ concentrations in the garden soils as compared to As, averaging 30.3 and $6.9 \mathrm{mg} / \mathrm{kg}$ for soil $\mathrm{Pb}$ and As respectively.

Also consistent with previous research $[31,33,34]$, leaf tissues concentrated $\mathrm{As}$ and $\mathrm{Pb}$ more heavily than the flesh of plants, with As TFs averaging 0.204 and 0.022 for leaf and flesh tissues respectively, and $\mathrm{Pb}$ TFs averaging 0.117 and 0.005 for leaf and flesh tissues. Higher tissue concentrations in leafy plant tissues may be due to leafy plants and herbs propensity to grow at faster rates and have higher transpiration rates than non-leaf plants [35]. Foliar metal uptake in leaves may also contribute to higher leaf tissue metal concentrations [36]. A general, albeit not statistically-significant $(\alpha=0.05)$, trend of increased $\mathrm{Pb}$ and $\mathrm{As}$ concentration in leaf tissues was observed with increasing total soil metal concentration, while no such trend was observed for flesh plant tissues (Figure 3). Culantro, 
in the Apiaceae family, had the highest TF of the plant samples in our study. Other studies have found similarly high uptake and concentration of metals, including As and $\mathrm{Pb}$, in cilantro, a plant similar to culantro also in the Apiaceae family, and other herbs compared to other garden plant types [37-39]. To our knowledge, TFs for culantro have not been previously reported in the literature.

While beyond the scope of this study, additional factors should be considered when determining exposure risk from consumption of garden plants. For example, while TFs were generally higher for leaf plant tissues than flesh, the amount of each food typically consumed should also be considered when determining exposure risk. Additionally, adherence of contaminated soil onto plant tissue can also contribute to exposure through handling or consumption of unwashed plants [20].

Because site-specific exposure data, including soil metal bioavailability/bioaccessibility and plant uptake, may differ from default assumptions, consideration of such data can improve accuracy and reduce uncertainty in risk determination from potential exposure to $\mathrm{As}, \mathrm{Pb}$, or other toxic metals from urban gardening related activities.

Acknowledgments: The authors would like to thank Katia Aviles from Proyecto Enlace for her support in this study. We also want to acknowledge Yolianne Maclay and Alex Rivera from the EPA's Caribbean Environmental Protection Division (CEPD) for collecting the study samples.

Author Contributions: John Misenheimer, Clay Nelson, Karen Bradham, Evelyn Huertas and Myriam Medina-Vera conceived and designed the experiments. Myriam Medina-Vera modified and translated the sampling protocol. Evelyn Huertas, Karen Bradham, and Myriam Medina-Vera coordinated field collection of samples. John Misenheimer, Clay Nelson and Alex Prevatte performed sample analysis. John Misenheimer and Clay Nelson led manuscript writing. All coauthors assisted with final reviews and editing of the manuscript.

Conflicts of Interest: The authors declare no conflict of interest.

Disclaimer: This article was reviewed in accordance with the policy of the National Exposure Research Laboratory, U.S. Environmental Protection Agency, and approved for publication. Approval does not signify that the contents necessarily reflect the views or policies of the U.S. Environmental Protection Agency.

\section{References}

1. U.S. Environmental Protection Agency (USEPA). Brownfields and Urban Agriculture: Interim Guidelines for Safe Gardening Practices. 2011. Available online: https:/ /www.epa.gov/sites/production/files/2015-09/ documents/bf_urban_ag.pdf (accessed on 15 February 2017).

2. Adriano, D. Trace Elements in Terrestrial Environments. In Biogeochemistry, Bioavailability and Risks of Metals; Springer-Verlag: New York, NY, USA, 2001.

3. Alloway, J. Heavy Metals in Soils; Blackie and Son: London, UK, 1990.

4. U.S. Environmental Protection Agency (USEPA). Guidance for Evaluating the Oral Bioavailability of Metals in Soils for Use in Human Health Risk Assessment; OSWER 9285.7-80; USEPA: Washington, DC, USA, 2007.

5. Bradham, K.; Scheckel, K.; Nelson, C.; Seales, P.; Lee, G.; Hughes, M.; Miller, B.; Yeow, A.; Gilmore, T.; Harper, S.; et al. Relative Bioavailability and Bioaccessibility and Speciation of Arsenic in Contaminated Soils. Environ. Health Perspect. 2011, 119, 1629-1634. [CrossRef] [PubMed]

6. Ramirez-Andreotta, M.; Brusseau, M.; Artiola, J.; Maiera, R. A greenhouse and field-based study to determine the accumulation of arsenic in common homegrown vegetables grown in mining-affected soils. Sci. Total Environ. 2013, 443, 299-306. [CrossRef] [PubMed]

7. Peryea, F.J. Gardening on Lead- and Arsenic-Contaminated Soils. 2015. Available online: http:/ / www.ecy. wa.gov/programs/tcp/area_wide/AW/AppK_gardening_guide.pdf (accessed on 16 February 2015).

8. Moir, A.M.; Thornton, I. Lead and cadmium in urban allotment and garden soils and vegetables in the United Kingdom. Environ. Geochem. Health 1989, 11, 113-119. [CrossRef] [PubMed]

9. Davies, B.E. Plant-available lead and other metals in British garden soils. Sci. Total Environ. 1978, 9, $243-262$. [CrossRef]

10. Xu, J.; Thornton, I. Arsenic in garden soils and vegetable crops in Cornwall, England: Implications for human health. Environ. Geochem. Health 1985, 7, 131-133. [CrossRef] [PubMed]

11. Chang, C.Y.; Yu, H.Y.; Chen, J.J.; Li, F.B.; Zhang, H.H.; Liu, C.P. Accumulation of heavy metals in leaf vegetables from agricultural soils and associated potential health risks in the Pearl River Delta, South China. Environ. Monit. Assess. 2014, 186, 1547-1560. [CrossRef] [PubMed] 
12. Puerto Rico. $18^{\circ} 25^{\prime} 37^{\circ} \mathrm{N} 66^{\circ} 03^{\prime} 09^{\prime}$ W. Google Earth. Available online: http:/ / satellites.pro/Puerto_Rico\#18. 034998,-66.282891,11 (accessed on 3 January 2018).

13. U.S. Environmental Protection Agency (USEPA). Guidance for Sample Collection for In Vitro Bioaccessibility Assay for Lead (Pb) in Soil; OSWER 9200.3-100; USEPA: Washington, DC, USA, 2015.

14. Pastaka, R. Traditional Malawian Dishes. Available online: http://honestcooking.com/six-traditionalmalawian-dishes / (accessed on 8 March 2016).

15. Maundu, P.M. The Status of Traditional Vegetable Utilization in Kenya. 1995. Available online: http:/ / www.bioversityinternational.org/fileadmin/bioversity/publications/Web_version/500/ch09.htm\# The\%20status\%20of\%20traditional\%20vegetable\%20utilization\%20in\%20Kenya (accessed on 8 March 2016).

16. Commission, S.P. South Pacific Foods, Leaflet No. 12-Pumpkin. 1995. Available online: http:/ /www.fao. org/WAIRdocs / x5425e/x5425e00.htm\#Contents (accessed on 9 March 2016).

17. Rayment, G.; Higginson, F. Australian Laboratory Handbook of Soil and Water Chemical Methods; Inkata Press: Melbourne, Australia, 1992; Volume 3.

18. Teaf, C.M.; Covert, D.J.; Teaf, P.A.; Page, E.; Starks, M.J. Arsenic Cleanup Criteria for Soils in the US and Abroad: Comparing Guidelines and Understanding Inconsistencies. In Proceedings of the Annual International Conference on Soils, Sediments, Water and Energy, Amherst, MA, USA, 18-21 October 2010; Volume 15, Article 10.

19. U.S. Environmental Protection Agency (USEPA). Clarification to the 1994 Revised Interim Soil Lead Guidance for CERCLA Sites and RCRA Corrective Action Facilities; OSWER 9200.4-27; USEPA: Washington, DC, USA, 1998.

20. U.S. Environmental Protection Agency (USEPA). Technical Review Workgroup Recommendations Regarding Gardening and Reducing Exposure to Lead-contaminated Soils; OSWER 9200.2-142; USEPA: Washington, DC, USA, 2014.

21. U.S. Environmental Protection Agency (USEPA). SW-846 Update VI. Method 1340 In Vitro Bioaccessibility Assay for Lead in Soil; Revision 1; USEPA: Washington, DC, USA, February 2017.

22. Diamond, G.L.; Bradham, K.D.; Brattin, W.J.; Burgess, M.; Griffin, S.; Hawkins, C.A.; Juhasz, A.L.; Klotzbach, J.M.; Nelson, C.; Lowney, Y.W.; et al. Predicting oral relative bioavailability of arsenic in soil from in vitro bioaccessibility. J. Toxicol. Environ. Health A 2016, 79, 165-173. [CrossRef] [PubMed]

23. Harrison, R.M.; Chirgawi, M.B. The assessment of air and soil as contributors of some trace metals to vegetable plants III. Experiments with field-grown plants. Sci. Total Environ. 1989, 83, 47-62. [CrossRef]

24. Cave, M.R.; Wragg, J.; Harrison, H. Measurement modelling and mapping of arsenic bioaccessibility in Northampton, United Kingdom. J. Environ. Sci. Health Part A 2013, 48, 629-640. [CrossRef] [PubMed]

25. Juhasz, A.L.; Smith, E.; Weber, J.; Rees, M.; Rofe, A.; Kuchel, T.; Sansom, L.; Naidu, R. Comparison of in vivo and in vitro methodologies for the assessment of arsenic bioavailability in contaminated soils. Chemosphere 2007, 69, 961-966. [CrossRef] [PubMed]

26. U.S. Environmental Protection Agency (USEPA). Guidance Manual for the Integrated Exposure Uptake Biokinetic Model for Lead in Children; OSWER 9285.7-15-1; USEPA: Washington, DC, USA, 1994.

27. U.S. Environmental Protection Agency (USEPA). Recommendations for Default Value for Relative Bioavailability of Arsenic in Soil; OSWER 9200.1-113; USEPA: Washington, DC, USA, 2012.

28. Brattin, W.; Drexler, J.; Lowney, Y.; Griffin, S.; Diamond, G.; Woodbury, L. An in vitro method for estimation of arsenic relative bioavailability in soil. J. Toxicol. Environ. Health A 2013, 76, 458-478. [CrossRef] [PubMed]

29. Bradham, K.D.; Nelson, C.; Juhasz, A.L.; Smith, E.; Scheckel, K.; Obenour, D.R.; Miller, B.W.; Thomas, D.J. Independent data validation of an in vitro method for the prediction of the relative bioavailability of arsenic in contaminated soils. Environ. Sci. Technol. 2015, 49, 6312-6318. [CrossRef] [PubMed]

30. U.S. Environmental Protection Agency (USEPA). Soil Screening Guidance: Technical Background Document; OSWER 9355.4-17A; USEPA: Washington, DC, USA, 1996.

31. Liu, H.; Probst, A.; Liao, B. Metal contamination of soils and crops affected by the Chenzhou lead/zinc mine spill (Hunan, China). Sci. Total Environ. 2005, 339, 153-166. [CrossRef] [PubMed]

32. Defoe, P.P.; Hettiarachchi, G.M.; Benedict, C.; Martin, S. Safety of gardening on lead and arsenic contaminated urban brownfields. J. Environ. Qual. 2014, 43, 2064-2078. [CrossRef] [PubMed]

33. Zhuang, P.; McBride, M.B.; Xia, H.; Li, N.; Li, Z. Health risk from heavy metals via consumption of food crops in the vicinity of Dabaoshan mine, South China. Sci. Total Environ. 2009, 407, 1551-1561. [CrossRef] [PubMed] 
34. Merecki, N.; Agic, R.; Sunic, L.; Milenkovic, L.; Illic, Z.S. Transfer factor as indicator of heavy metals content in plants. Fresen. Environ. Bull. 2015, 24, 4212-4219.

35. Luo, C.L.; Liu, C.P.; Wang, Y.; Liu, X.; Li, F.B.; Zhang, C.; Li, X.D. Heavy metal contamination in soils and vegetables near an e-waste processing site, south China. J. Hazard. Mater. 2011, 186, 481-490. [CrossRef] [PubMed]

36. Shahid, M.; Dumat, C.; Khalid, S.; Schreck, E.; Xiong, T.; Niazi, N.K. Foliar heavy metal uptake, toxicity and detoxification in plants: A comparison of foliar and root metal uptake. J. Hazard. Mater. 2017, 325, 36-58. [CrossRef] [PubMed]

37. Finster, M.E.; Gray, K.A.; Binns, H.J. Lead levels of edibles grown in contaminated residential soils: A field survey. Sci. Total Environ. 2004, 320, 245-257. [CrossRef] [PubMed]

38. Roychowdhury, T.; Uchino, T.; Tokunaga, H.; Ando, M. Survey of arsenic in food composites from an arsenic affected area of West Bengal, India. Food Chem. Toxicol. 2002, 40, 1611-1621. [CrossRef]

39. Bundschuh, J.; Nath, B.; Bhattacharya, P.; Liu, C.; Armineta, M.A.; Lopez, M.V.M.; Lopez, D.L.; Jean, J.; Cornejo, L.; Macedo, L.F.L.; et al. Arsenic in the human food chain: The Latin American perspective. Sci. Total Environ. 2012, 429, 92-106. [CrossRef] [PubMed]

(C) 2018 by the authors. Licensee MDPI, Basel, Switzerland. This article is an open access article distributed under the terms and conditions of the Creative Commons Attribution (CC BY) license (http://creativecommons.org/licenses/by/4.0/). 